\title{
Content of bioactive compounds and antioxidant activity in garlic (Allium sativum L.)
}

\author{
Marianna MICOVÁ ${ }^{1 *}$, Judita BYSTRICKÁ ${ }^{2}$, Ján KOVAROVIČ ${ }^{1}$, Luboš HARANGOZO ${ }^{1}$, Adriana LIDIKOVÁ ${ }^{3}$
}

Received April 23, 2018; accepted November 30, 2018.

Delo je prispelo 23. aprila 2018, sprejeto 30. novembra 2018.

\begin{abstract}
Garlic (Allium sativum L.) is highly regarded throughout the world for both its medicinal and culinary properties. With its bioactive compounds and sulphur containing compounds, high trace mineral content, garlic has shown anti-viral, antibacterial, anti-fungal and antioxidant abilities.

This work has focused on the measurement and comparison of the total polyphenols content, the total sulphur content and antioxidant activity of the studied varieties of garlic in the area of Nitra and Bardejov, Slovak Republic. The highest content of monitored indicators (TPC, TSC, AOA) was measured in the area of Nitra. TPC was determined using the spectrophotometric method of Folin-Ciocalteu agents. The total polyphenols content were determined in the range 621.13 to $763.28 \mathrm{mg} \mathrm{kg}^{-1}$ in area of Nitra. The content of total sulphur compounds in the area of Nitra ranges from 0.562 to $0.800 \%$ and in the second area ranges from $0.421 \%$ to $0.658 \%$. Antioxidant activity was measured by the spectrophotometric method using a compound DPPH. The value of antioxidant activity ranged from $12.01 \%$ to $20.22 \%$ in both monitored locations. The content of TPC, TSC and AOA beside the variety may be affected by the localitylinked factors like climatic conditions and the agrochemical composition of the soil.
\end{abstract}

Key words: antioxidant activity; garlic; polyphenols; sulphur compounds

\section{IZVLEČEK}

\section{VSEBNOST BIOAKTIVNIH SNOVI IN ANTIOKSIDACIJSKA AKTIVNOST ČESNA (Allium sativum L.)}

Česen (Allium sativum L.) je zelo cenjen po celem svetu zaradi njegovih zdravilnih in kulinaričnih lastnosti. Na osnovi žveplo vsebujočih bioaktivnih snovi in elementov $\mathrm{v}$ sledeh ima protivirusne, protibakterijske, protiglivne in antioksidacijske lastnosti.

Raziskava se osredotoča na meritve im primerjave vsebnosti polifenolnih in žveplo vsebujočih snovi v preučevanih sortah česna na območju Nitre in Bardejova, Slovaška Republika. Največja vsebnost merjenih indikatorjev (TPC, TSC, AOA) je bila izmerjena na območju Nitre. TPC je bil določen $s$ spektrofotometrično metodo $\mathrm{z}$ uporabo Folin-Ciocalteujevega reagenta. Celokupna vsebnost polifenolov, izmerjena na območju Nitre je bila v razponu od 621,13 do 763,28 mg kg${ }^{1}$.Celokupna vsebnost žveplo vsebujočih snovi je bila na območju Nitre v razponu od 0,562 do $0,800 \%$ in od $0,421 \%$ do $0,658 \%$ na drugem preučevanem območju. Antioksidacijska aktivnost je bila izmerjena spektrofotometrično $\mathrm{z}$ uporabo DPPH. Antioksidacijska aktivnost je bila $\mathrm{v}$ obeh preučevanih območjih $\mathrm{v}$ razponu od $12,01 \%$ do 20,22 \%. Na vsebnost TPC, TSC in AOA vplivajo poleg sorte z lokacijo povezani dejavniki kot so podnebne razmere, sestava tal in uporabljena agrotehnika.

Ključne besede: antioksidacijska aktivnost; česen; polifenoli; žveplove spojine

\footnotetext{
1 Ing., Slovak University of Agriculture in Nitra, Faculty of Biotechnology and Food Sciences, Department of Chemistry, Tr. A. Hlinku 2, 94976 Nitra, Slovak Republic; *Corresponding author: xlenkova@is.uniag.sk

2 Assoc. Prof. Ing., PhD., Slovak University of Agriculture in Nitra, Faculty of Biotechnology and Food Sciences, Department of Chemistry, Tr. A. Hlinku 2, 94976 Nitra, Slovak Republic

3 Slovak University of Agriculture in Nitra, Faculty of Biotechnology and Food Sciences, Department of Chemistry, Tr. A. Hlinku 2, 94976 Nitra, Slovak Republic
} 


\section{INTRODUCTION}

Garlic (Allium sativum L.) is a plant of the genus Alliaceae and is one of the longest cultivated crop plants in the world. It is known that it was used for healing purposes in the Middle Ages. Garlic is an important raw material of plant origin with observed and proven positive effects on the human organism. Garlic has a versatile use as a spice and also uses its healing properties. It is believed to originate in Central Asia, where it originated from the wildly growing species Allium longicuspis Regel (Iciek et al., 2012). Garlic was extended to the West, South and East more than 6000 years ago. Garlic, as we know it today, has been used in Chinese medicine for 3000 years ago. Egyptians used garlic to increase immunity and protect against various diseases and to improve performance (Sultan et al., 2014). Louis Pasteur, the famous bacteriologist found that garlic juice kills bacteria propagated at a laboratory dish. From this time on, it has been shown many times that garlic destroys a very wide range of bacteria and fungi that adversely affect our health (Fulder, 2002). In the past, garlic was used as a medicine during various epidemics such as typhus, dysentery, cholera and influenza. At present, garlic is grown around the world. In our territory, it is used as an important preventive medicine, universal spice and food (Petrovská \& Čekovská, 2010). Several studies have shown multifaceted health benefits of garlic, it is recommended as a dietary supplement worldwide. The evidence of health effects has increased its consumption especially in the culinary field (Suleria et al., 2015). Current knowledge indicates that nature around us is a great source of available health-promoting and chemopreventive agents. Chemoprotective substances are part of foods of plant origin where they occur as natural ingredients.

Garlic (Allium sativum L.) is a source of biologically active compounds such as phenolic acids, flavonoids, sulphur compounds, vitamins, minerals and others. Garlic is a good source of important vitamins. Although the amount of garlic consumed is not such as to cover the need for the body, sulphur compounds contained in garlic can enhance the effects of vitamins. Vitamin $B_{1}$ (thiamine) is easily absorbed in the intestines in combination with allicin. Garlic contains B vitamins $\left(\mathrm{B}_{1}, \mathrm{~B}_{3}, \mathrm{~B}_{5}\right.$ and $\left.\mathrm{B}_{6}\right)$, vitamins $\mathrm{C}$ and $\mathrm{E}$. The content of individual vitamins in garlic is different and depends on many factors - variety, storage, treatment and cultivation (Butt \& Sultan, 2009).

Garlic belongs to the important and significant vegetables, characterized by significantly high content of polyphenolic compounds positively affecting human body. The majority of polyphenol compounds in garlic are phenolic acids and flavonoids (Piazzon et al., 2012;
Obied, 2013). Polyphenols are heterogeneous oligo- or polymeric compounds combined with other compounds (Xiao et al., 2013). Polyphenols in plants fulfil important functions: they are carriers of flavours, fragrances and colorants, are building and structural components, and are defensive substances (from pests, various infections, pathogens and mechanical damage) (Knežević et al., 2012). Polyphenol compounds according to the chemical structure are divided into phenolic acids, flavonoids, lignans and stilbenes (Pereira et al., 2009). The total polyphenol content of the garlic can be influenced by the variety (Srivastava et al., 2013), as well as storage and technological processing of garlic (Süli et al., 2014). The physiological effect of polyphenols is wide ranging and shows antioxidant, anti-carcinogenic, anti-mutagenic, antibacterial, anti-parasitic, and antidiabetic activity (Obied, 2013).

For characteristic aroma and flavour of garlic are responsible sulphur compounds in garlic. These substances are physiologically active and used as antibiotics, particularly in the treatment of gastric cancer (Harris, 2004). The antibiotic value is influenced by the components: allicin, S-methylcysteine sulfoxide and Spropylcysteine sulfoxide. Allicin is the main biologically active ingredient of garlic (Lanzotti, 2006). Allicin is not found in garlic, it is produced by the enzyme allinase from alliin. After processing, such as cutting, crushing, chewing or dehydration, alliin is converted to allicin by allinase (Amagase et al., 2001; Bhuiyan et al., 2015). Sulphur compounds are very effective anticoagulant, prolong the clotting and promote blood circulation (Oberbeil \& Lentzová, 2005). Sulphur compounds are characterized by their ability to support the immune system and also protect the cardiovascular system (Kačániová \& Tančinová, 2012).

Garlic (Allium sativum L.) acts as a natural antioxidant and plays an important role in chemoprevention of many civilization diseases (Hamzah et al., 2013). Garlic is rich in antioxidant phytochemicals that prevent oxidative damage. In blood serum, bioactive compounds of garlic eliminate hydroxyl radicals and increase the activity of some enzymes with antioxidant effects. These include flavonoids and sulphur compounds soluble in water (S-allylcysteine and Sallylmercaptocysteine) and fat-soluble (allicin and its products) and selenium (Borek, 2001).

In the present work we evaluated the beneficial effects of the total polyphenols content, sulphur compounds and antioxidant activity in individual varieties (Mojmír, Lukan, Záhorský, Havran, Makoi) of garlic (Allium sativum L.) and we evaluated the impact of two sites 
(Nitra, Bardejov) on the total content of polyphenols, the total content of sulphur compounds and antioxidant activity in selected garlic varieties.

\section{MATERIALS AND METHODS}

\subsection{The local climate conditions}

This study was performed in area of Nitra and Bardejov, Slovak Republic. Nitra is situated on the south-western Slovakia in the area of Podunajská lowland. Nitra belongs to warmer and dry areas with mild winters in Slovakia. The average annual rainfall is $550-600 \mathrm{~mm}$ and the average annual temperature is $9-10^{\circ} \mathrm{C}$. Bardejov is located in the north-eastern Slovakia. Bardejov belongs to slightly warm and mountaincontinental climate area. The average annual rainfall is $700-750 \mathrm{~mm}$ and the average annual temperature is 5 $9{ }^{\circ} \mathrm{C}$. Nitra and Bardejov have very good natural and climatic conditions for crop growth, without any adverse effects.

\subsection{Samples of plant material}

The samples of plant material (5 variety of garlic 'Mojmír', 'Záhorský', 'Lukan', 'Havran', 'Makoi') were collected in the phase of full ripeness from area of Nitra and Bardejov, Slovak republic. For analysis was used fresh material soil samples and plant. Samples were analysed by selected methodologies (determination of total polyphenols, total sulphur compounds and antioxidant activity). All samples of plant material were grown under the same conditions. The soil samples from the area, where was grown plant material, was analysed (Table 1 and Table 2). The analysis of soil samples was carried out four times in four sampling sites with pedological probe Geosampler Fisher. Only NPK fertilization $\left(200 \mathrm{~g} \mathrm{~m}^{-2}\right)$ was used for the achievement of favourable soil macroelements content.

Table 1: Agrochemical characteristic of soil substrate in $\mathrm{mg} \mathrm{kg}^{-1}$, content of nutrients from locality Nitra and Bardejov

\begin{tabular}{llllllll}
\hline Locality & $\mathrm{K}$ & $\mathrm{Ca}$ & $\mathrm{Mg}$ & $\mathrm{P}$ & $\mathrm{pH}_{\mathrm{KCl}}$ & Humus \% & Cox \% \\
\hline \multirow{3}{*}{ Nitra } & 399.2 & 3861.4 & 1312 & 97.6 & 6.91 & 2.9 & 1.68 \\
& \pm & \pm & \pm & \pm & \pm & \pm & \pm \\
& 2.1 & 7.1 & 4 & 1.6 & 0.06 & 0.1 & 0.01 \\
& 380.1 & 2170.8 & 259 & 406.7 & 5.51 & 3.58 & 6.17 \\
Bardejov & \pm & \pm & \pm & \pm & \pm & \pm & \pm \\
& 2.7 & 2.2 & 1.2 & 1.7 & 0.09 & 0.03 & 0.01 \\
\hline
\end{tabular}

Table 2: Content of heavy metals $\left(\mathrm{mg} \mathrm{kg}^{-1}\right)$ in soil substrate (extraction by aqua regia)

\begin{tabular}{llllll}
\hline Locality & $\mathrm{Zn}$ & $\mathrm{Cu}$ & $\mathrm{Ni}$ & $\mathrm{Pb}$ & $\mathrm{Cd}$ \\
\hline \multirow{3}{*}{ Nitra } & 55.2 & 27.8 & 42.6 & 40.3 & 4.2 \\
& \pm & \pm & \pm & \pm & \pm \\
& 2.3 & 1.4 & 1.8 & 1.6 & 0.04 \\
\multirow{2}{*}{ Bardejov } & \pm 0.1 & 33.5 & 37.7 & 19.2 & 1.9 \\
& \pm & \pm & \pm & \pm & \pm \\
Limit $^{1}$ & 2.9 & 1.2 & 1.6 & 1.1 & 0.1 \\
& 150 & 60 & 50 & 70 & 0.7
\end{tabular}

${ }^{1}$ Limit value for aqua regia - Law No. 220/2004 


\subsection{Sample preparation}

Extract was prepared from the $25 \mathrm{~g}$ samples garlic, which were shaken (shaker GFL 3006, $125 \mathrm{rpm}$ ) in 50 $\mathrm{ml}$ of $80 \%$ ethanol for sixteen hours. Samples were kept at laboratory room temperature in dark conditions until the analysis. Each determination was carried out in six replications.

\subsection{Determination of total polyphenols}

Total polyphenols content (TPC) was determined by the method according to Lachman et al. (2003). It is expressed as $\mathrm{mg}$ of gallic acid equivalent per $\mathrm{kg}$ of fresh matter. Total polyphenols content was determined using the Folin-Ciocalteu reagent. $2.5 \mathrm{ml}$ of Folin-Ciocalteu reagent was added to $0.1 \mathrm{ml}$ extract to volumetric flask. The content was mixed. After 3 minutes, $5 \mathrm{ml} 20 \%$ solution of sodium carbonate was added. Then the volume was adjusted to $50 \mathrm{ml}$ with distilled water. After 2 hours, the samples were centrifuged (centrifuges UNIVERSAL 320, $15000 \mathrm{rpm}$ ) for 10 minutes. The absorbance was measured by use of spectrophotometer Shimadzu UV/VIS - 1240 at $765 \mathrm{~nm}$. The concentration of polyphenols was calculated from a standard curve with known concentration of gallic acid.

\subsection{Determination of total sulphur compounds}

The determination of the total sulphur content is based on dry combustion in the presence of oxygen and allows for the quantitative conversion of sulphur to $\mathrm{SO}_{2}$, the elimination of other combustion products including water and the separation of the generated gases. $50 \mathrm{mg}$ of a lyophilized and homogenized sample is combusted in a tin crucible with a $\mathrm{V}_{2} \mathrm{O}_{5}$ catalyst in the elementar (Vario Macro Cube V 3.1.4, Elementar Analysensystem $\mathrm{GmbH})$. After insertion of the crucible with the sample into the combustion tube, the oxygen stream produces a strong exothermic reaction, the temperature rises to $1250{ }^{\circ} \mathrm{C}$ and the sample is combusted. Combustion products are conveyed along the combustion tube where the oxidation is complete. $\mathrm{SO}_{3}$ is reduced to $\mathrm{SO}_{2}$. The mixture of gases flows into the chromatographic column where the separation takes place. The gases are sent to the thermal conductivity detector where the electrical signals are processed by the software and provide the percentage of sulphur contained in the sample. Sulfanilamide is used as the calibration standard (Šapčanin et al., 2013).

\subsection{Determination of antioxidant activity}

Antioxidant activity (AOA) was measured according to Brand-Williams et al. (1995). The method is based on using $\mathrm{DPPH}^{\circ}$ (2.2-diphenyl-1-picrylhydrazyl). $\mathrm{DPPH}^{\circ}$ $(3.9 \mathrm{ml})$ was pipetted into the cuvette and the absorbance was measured using the spectrophotometer Shimadzu UV/VIS - 1240 at $515.6 \mathrm{~nm}$. The measured value corresponds to the initial concentration of $\mathrm{DPPH}^{\circ}$ solution at the time $\mathrm{A}_{0}$. Then $0.1 \mathrm{ml}$ extract was added to start measuring dependence $A=f(t)$. The content of cuvette was mixed and the absorbance was measured at 1,5 and 10 minutes in the same way as $\mathrm{DPPH}^{\circ}$ solution. The percentage of inhibition expresses how antioxidant compounds are able to remove $\mathrm{DPPH}^{*}$ radical at the given period.

Inhibition $(\%)=\left(\mathrm{A}_{0}-\mathrm{A}_{\mathrm{t}} / \mathrm{A}_{0}\right) \times 100$

\subsection{Statistical analysis}

Results were statistically evaluated by the Analysis of Variance (ANOVA - Multiple Range Tests, Method: 95.0 percent LSD) by using the statistical software STATGRAPHICS (Centurion XVI.I, USA).

\section{RESULTS AND DISCUSSION}

We analysed five varieties of garlic: Mojmír, Záhorský, Lukan, Havran and Makoi produced in two localities of Slovakia: Nitra and Bardejov. Each of the locations is characterized by a different annual average temperature, annual rainfall and agrochemical composition of the soil. The total content of polyphenols in the samples from the area Nitra ranged from $621.13 \pm 4.45$ to 763.28 $\pm 3.60 \mathrm{mg} \mathrm{kg}^{-1}$ (Figure 1). In area Bardejov, the total polyphenols content in the studied samples ranged from $559.68 \pm 2.26$ to $682.94 \pm 2.89 \mathrm{mg} \mathrm{kg}^{-1}$ (Figure 1). Statistically the highest content of total polyphenols was measured in the variety of garlic Havran and the lowest content of total polyphenols was found in the variety Záhorský in both study areas. The higher content of total polyphenols in the variety Havran was found in the area of Nitra and was 1.12-times higher, compared with the locality Bardejov. In other studied varieties of garlic higher total polyphenols content was found in the area of Nitra. Chekki et al. (2014) indicated, that the total polyphenols content in garlic is in the wide range from $436 \mathrm{mg} \mathrm{kg}^{-1}$ to $645 \mathrm{mg} \mathrm{kg}^{-1}$, which good correlate with the results of this work. Some authors reported even a higher value of TPC in garlic: $812 \mathrm{mg} \mathrm{kg}^{-1}$ (Charles, 2013), $1290 \mathrm{mg} \mathrm{kg}^{-1}$ (Wangcharoen \& Morasuk, 2009). In comparison with this study, lower content of TPC in garlic (493 $\mathrm{mg} \mathrm{kg}^{-1}$ ) was measured by Jastrzebski et al. (2007). The influence of the area on the content of total polyphenols was confirmed by the team of authors 
Hamouz et al. (2010). The above mentioned authors determined the total content of polyphenols by the same spectrophotometric method using the Folin-Ciocalteu reagent.

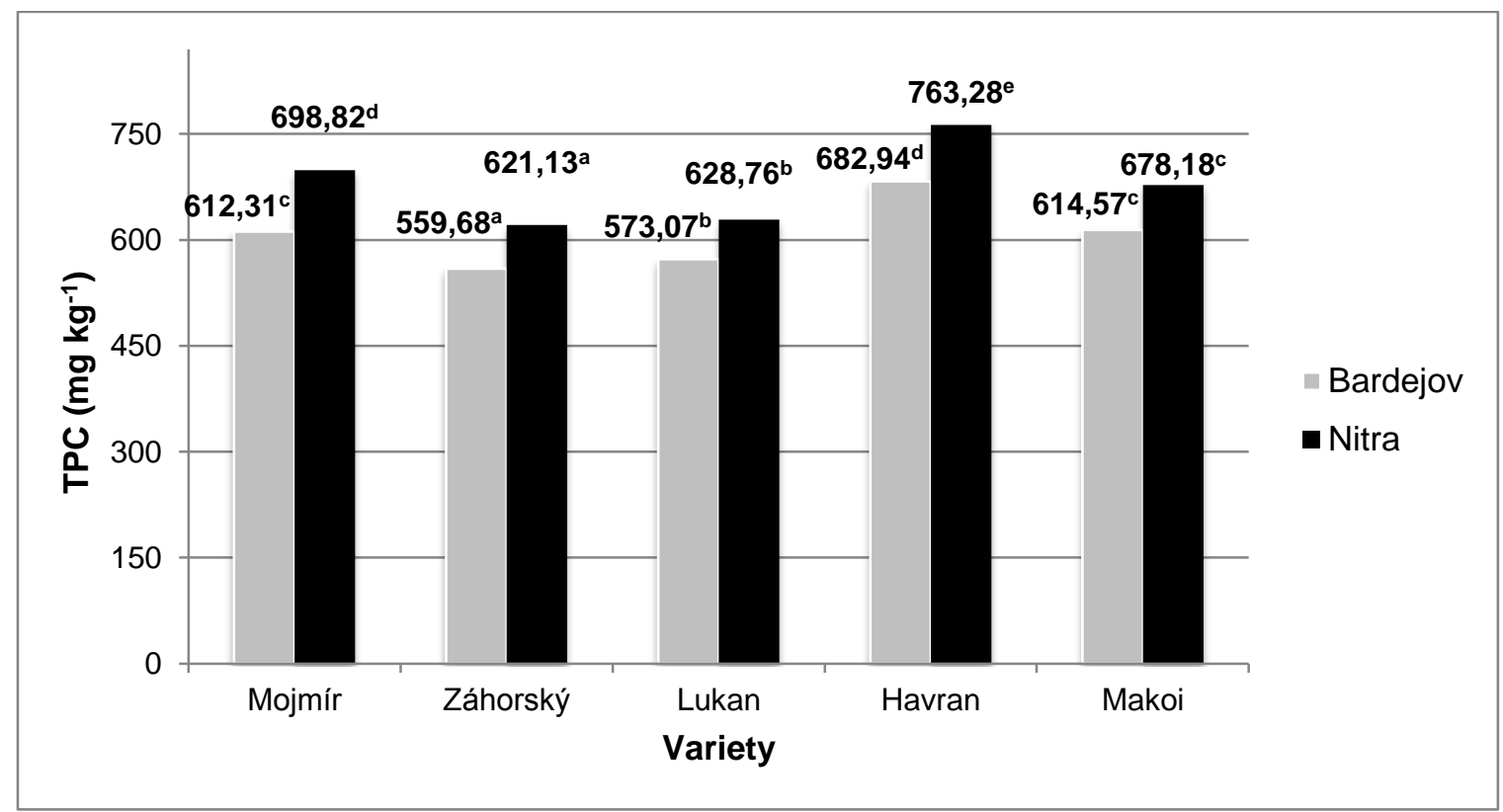

Figure 1: Average content of total polyphenols (TPC $\mathrm{m} \mathrm{kg}^{-1}$ ) from area Nitra and Bardejov

* Multiple Range Tests, Method: 95.0 percent LSD, Different letters (a, b, c, d and e) between the factors show statistically significant differences $(p<0.05)$

The values of antioxidant activity in the studied samples from the area Nitra are varied from $17.31 \%$ to $20.22 \%$ (Figure 2). The antioxidant activity of the samples from the area Bardejov ranged from $12.01 \%$ to $13.61 \%$ (Figure 2). Statistically the highest value of antioxidant activity was observed in the variety Havran and the lowest value of antioxidant activity was found in the variety Záhorský in both study areas. Higher value of antioxidant activity in the variety Havran was found in the area Nitra and was 1.13-times higher compared with the locality Bardejov. In other studied varieties of garlic was found higher value of antioxidant activity in the area Nitra. Statistically significant differences in the strength of antioxidant activity were also detected among all analysed varieties of garlic. Narendhirakannan \& Rajeswari (2010) indicate that the antioxidant activity in garlic ranges from $12 \%$ to $21 \%$ and antioxidant activity of garlic determined in this study is within this range. According to Rai et al. (2015) the antioxidant activity in garlic is $21.5 \%$. Choi et al. (2014) measured lower values of antioxidant activity in garlic $(7 \%)$. The cited authors determined the antioxidant activity of the method using $\mathrm{DPPH}^{-}$and their results were comparably expressed in percentage as in our work. 


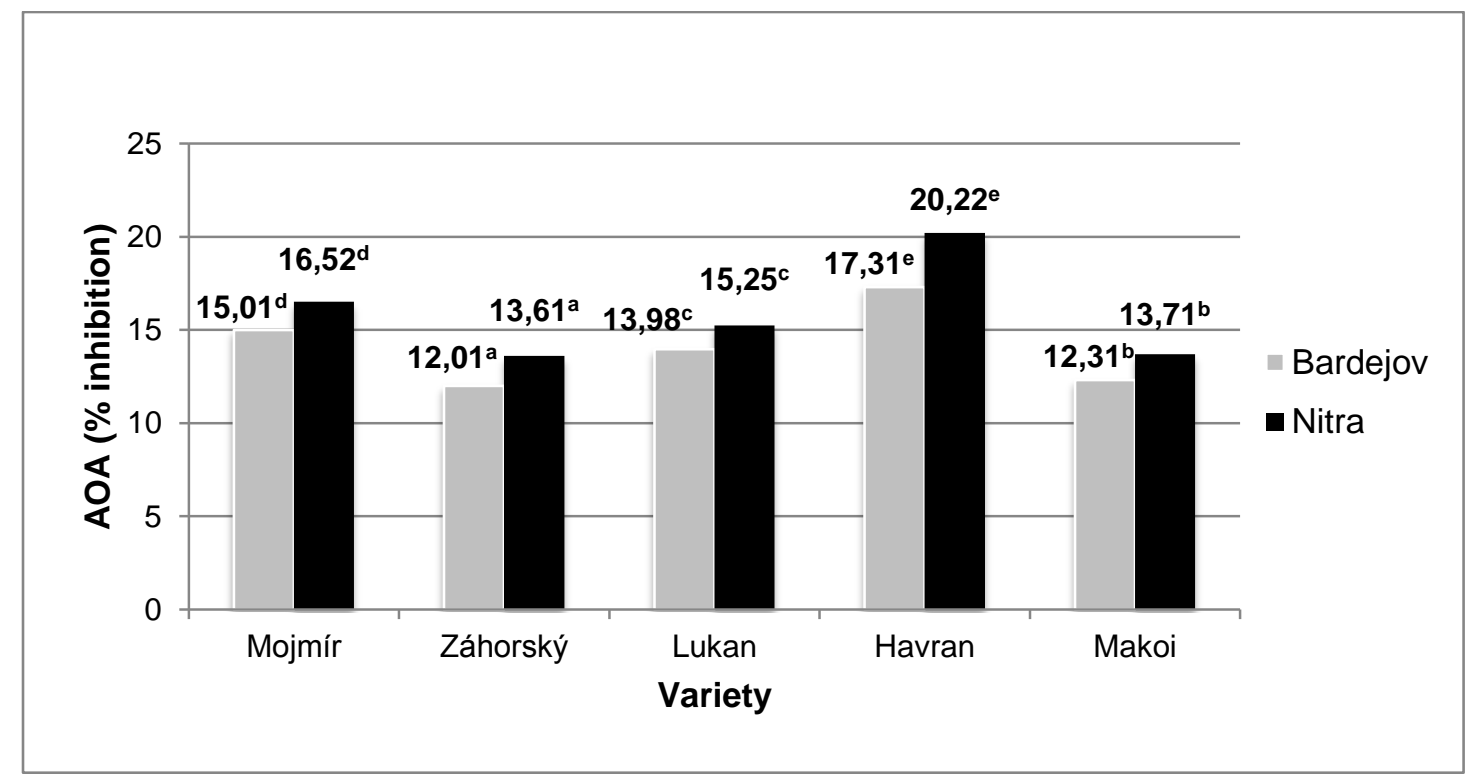

Figure 2: Average value of antioxidant activity (AOA \%) from area Nitra and Bardejov

* Multiple Range Tests, Method: 95.0 percent LSD, Different letters (a, b, c, d and e) between the factors show statistically significant differences $(p<0.05)$

The total sulphur content in the studied samples from area Nitra ranged from $0.562 \pm 0.042 \%$ to $0.800 \pm$ $0.048 \%$ (Figure 3). The total sulphur content in the studied samples from area Bardejov ranged from 0.421 $\pm 0.047 \%$ to $0.658 \pm 0.021 \%$. The highest content of total sulphur compounds of the analysed samples was measured in the variety Mojmír and the lowest total sulphur content was observed in the variety Záhorský in the both study areas. In other studied varieties of garlic was found higher total sulphur content in the area of Nitra, compared with the locality Bardejov. Benkeblia \& Lanzotti (2007) recorded, that the total sulphur content in garlic is $0.56 \%$. Muradić et al. (2010) mentioned value $0.63 \%$, which good correlate with the results of this work. Mahmutović et al. (2014) indicate, that the content of total sulphur compounds in garlic is in the range of $0.63 \%$ to $0.70 \%$. Munch (2013) report a lower total sulphur content in garlic $(0.3 \%)$.

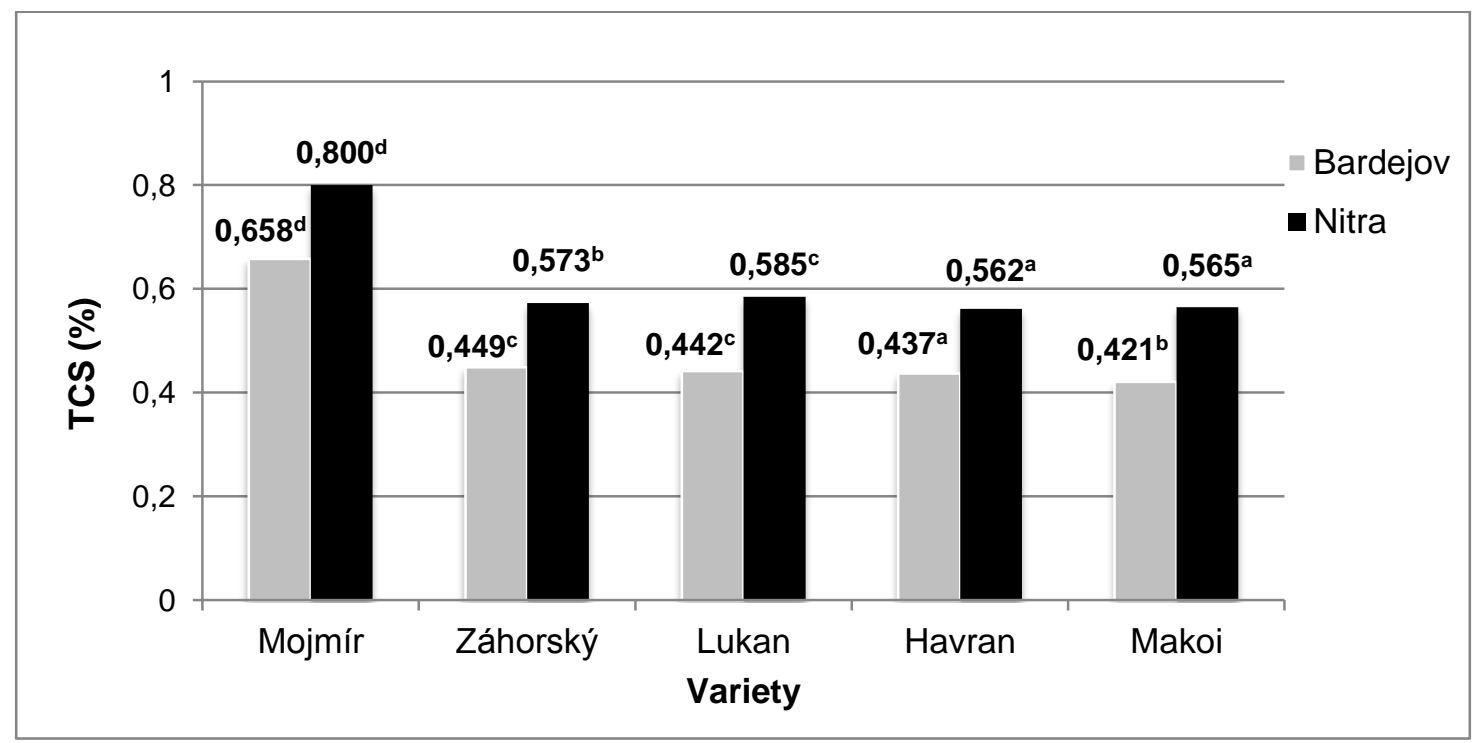

Figure 3: Average content of total sulphur compounds (TSC \%) from area Nitra and Bardejov

* Multiple Range Tests, Method: 95.0 percent LSD, Different letters (a, b, c and d) between the factors show statistically significant differences $(p<0.05)$ 
Khodadadi et al. (2015) in their experiment confirmed the site's impact on the content of sulphur compounds and also on the total polyphenols content and the value of antioxidant activity. Chekki et al. (2016) reported that the content of bioactive compounds is affected by the climatic conditions of the area. Sárosi et al. (2011) reported that the content of bioactive constituents in plants is heavily influenced by climatic conditions. Changing climatic conditions leads to stress in the plant. The content of total polyphenols and antioxidant activity are affected by sunny and warmer weather. In their work, they determined a higher content of total polyphenols and a higher value of antioxidant activity in a site with higher temperature and direct sunlight. This is well in agreement with ours results. Viljevac Vuletić et al. (2017) have indicated that higher level of precipitation at the site has a positive impact on the content of bioactive substances in the plant, which we unfortunately did not confirm in this study. The higher content of total polyphenols, sulphur compounds and antioxidant activity was recorded in the locality with increasing average annual temperature in Nitra. This area is characterized by a higher number of sunny days with an average annual temperature of 9 to $10^{\circ} \mathrm{C}$ and a lower annual rainfall $(550-600 \mathrm{~mm})$. Environmental influence on polyphenols synthesis is very important. Polyphenols, especially flavonoids are synthesized via the phenylpropanoid pathway with stimulation of light, which protects plants from harmful UV radiation acting as a protective filter. High temperatures during the season contributed to higher polyphenols content (Viljevac Vuletić et al., 2017).

In the locality of Nitra with a lower altitude $(151 \mathrm{~m}$ a.s.l.) we found a higher content of bioactive compounds compared to the area of Bardejov with a higher altitude (323 $\mathrm{m}$ a.s.l.), which is in agreement with the results of Fertout-Mouri et al. (2014) and Ghasemi et al. (2011). Changes in the content of total polyphenols, sulphur compounds and antioxidant activity may be affected not only by climate conditions but as well as agrochemical composition of the soil and fertilization (Huchette et al., 2005). A higher content of total polyphenols, sulphur compounds and antioxidant activity was observed in the studied varieties of garlic in the area of Nitra, which may correlate with higher levels of potassium and magnesium in the soil. Hamouz et al. (2010) also pointed out that the content of total polyphenols is affected by the content of potassium and magnesium in the soil. Mudau et al. (2007) state that higher potassium content positively affects the content of total polyphenols, at higher doses of potassium were recorded higher values of total polyphenols. According to Ruan et al. (1999) the polyphenol content in studied spring and autumn tea was enhanced by potassium application, while magnesium apparently decreased the polyphenol content. Kraus et al. (2004) reported that the site conditions affect plant phenolic concentrations and changes in soil pH affect nutrient availability. According to Ali et al. (2012) cultivation factors such as soil type, com-posts, mulching and fertilisation influence the water and nutrient supply to the plant and affect the nutritional composition and antioxidant activity. In their study higher total polyphenol content was determined by high $\mathrm{K}$ treatment. Climatic factors (such as temperature, sunny days, rainfall) and environmental factors, such as soil type, nutrient level and application strategy, influence the nutrient supply to the plant and could thereby affect concentrations and composition of the bioactive compounds.

Relations among the total polyphenols content, total sulfur content and the antioxidant activity in studied varieties of garlic (Mojmír, Záhorský, Lukan, Havran and Makoi) were evaluated (Figure 4-23). The coefficient of correlation $(r=0.9315-0.9978)$ confirmed strong dependency between the content of polyphenols, total sulfur content and the antioxidant activity and the results are in good agreement with the findings of Mahmutović et al. (2014), who confirmed correlations between total polyphenols content, total sulfur content and antioxidant activity in garlic. Ramkissoon et al. (2012), Chekki et al. (2014) indicated correlations between total polyphenols content and antioxidant activity in garlic, onion and other vegetable..

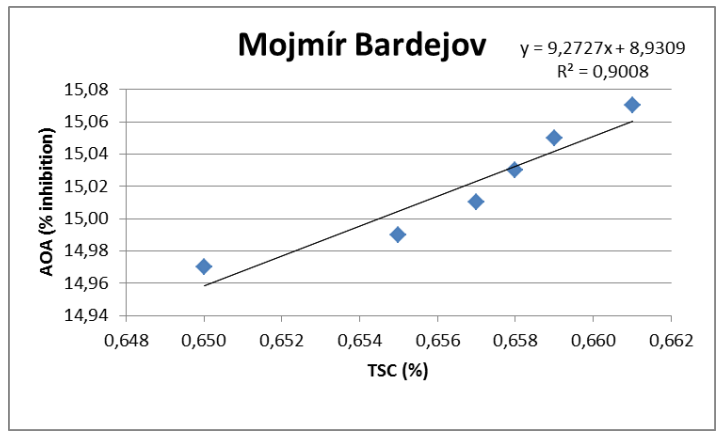

Figure 4: Relationship between TSC and AOA in 'Mojmír' 
Marianna MICOVÁ et al.

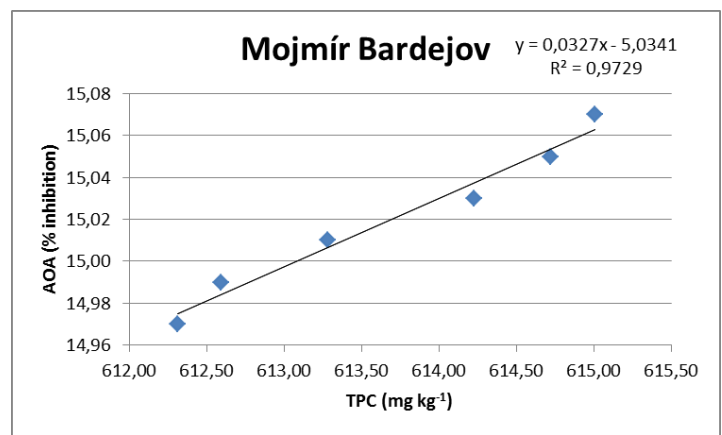

Figure 5: Relationship between TPC and AOA in 'Mojmír'

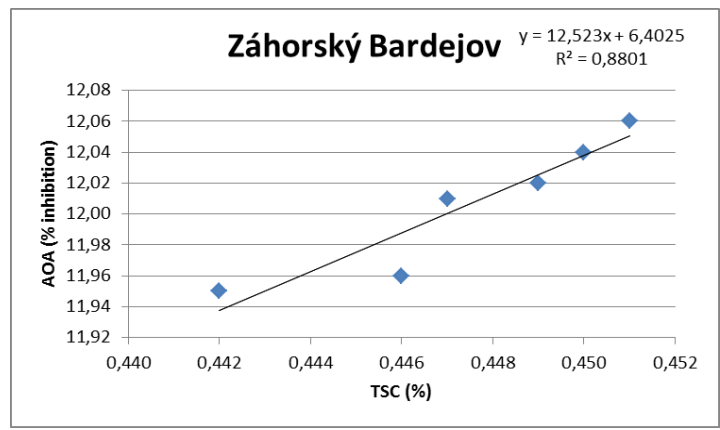

Figure 6: Relationship between TSC and AOA in 'Záhorský'

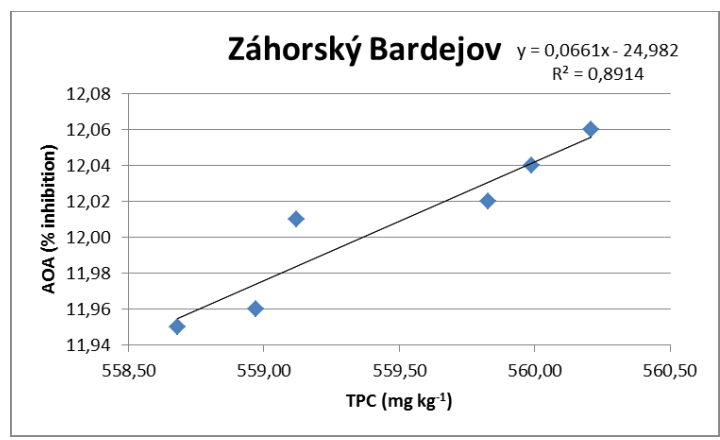

Figure 7: Relationship between TPC and AOA in 'Záhorský'

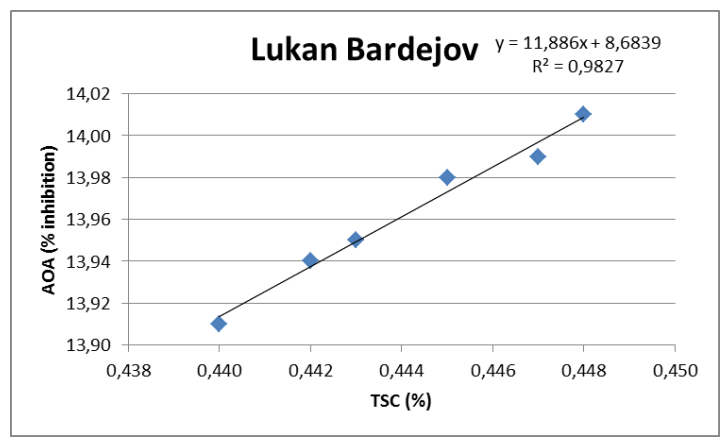

Figure 8: Relationship between TSC and AOA in 'Lukan' 


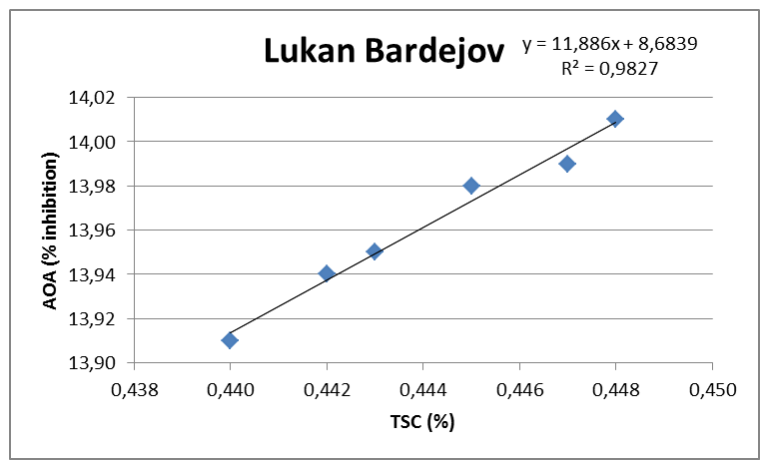

Figure 9: Relationship between TPC and AOA in 'Lukan'

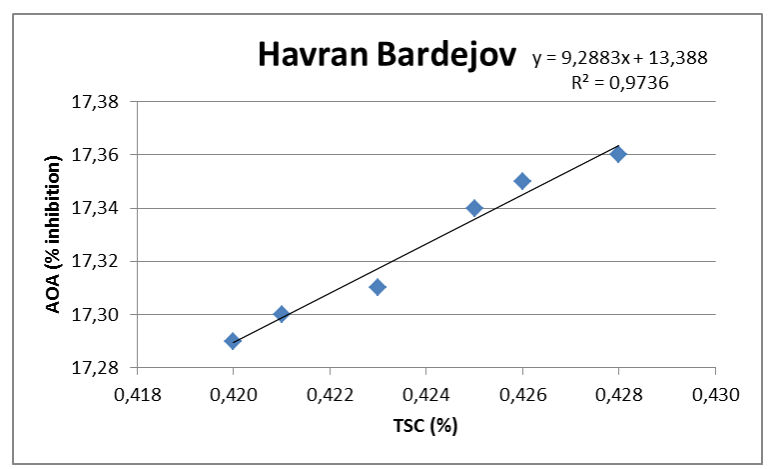

Figure 10: Relationship between TSC and AOA in 'Havran'

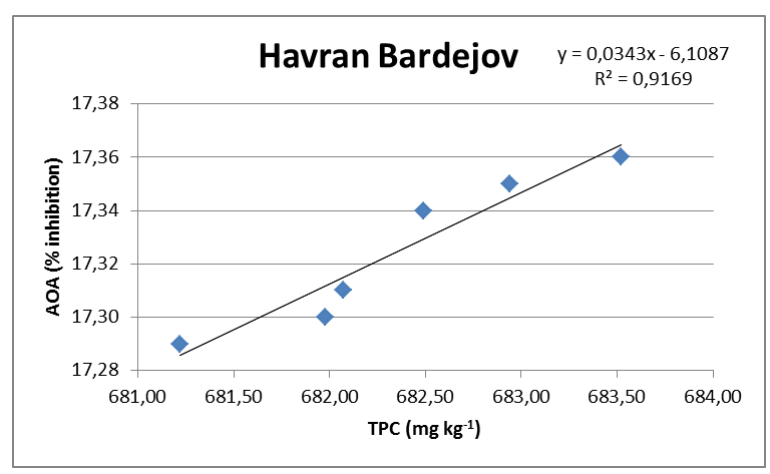

Figure 11: Relationship between TPC and AOA in 'Havran'

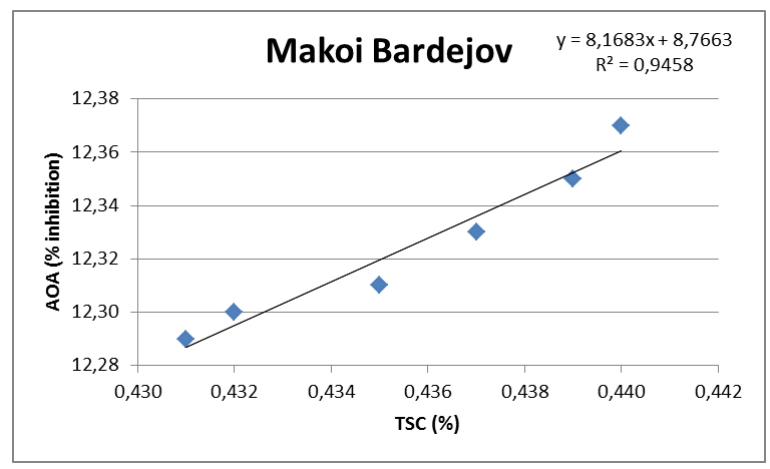

Figure 12: Relationship between TSC and AOA in 'Makoi' 
Marianna MICOVÁ et al.

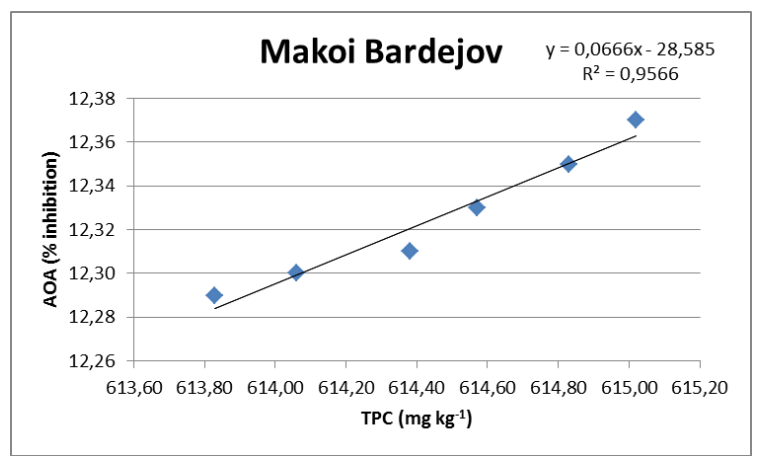

Figure 13: Relationship between TPC and AOA in 'Makoi'

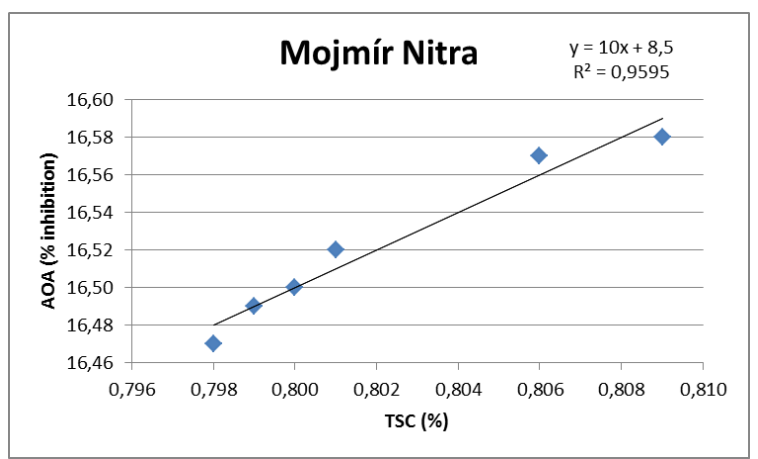

Figure 14: Relationship between TSC and AOA in 'Mojmír'

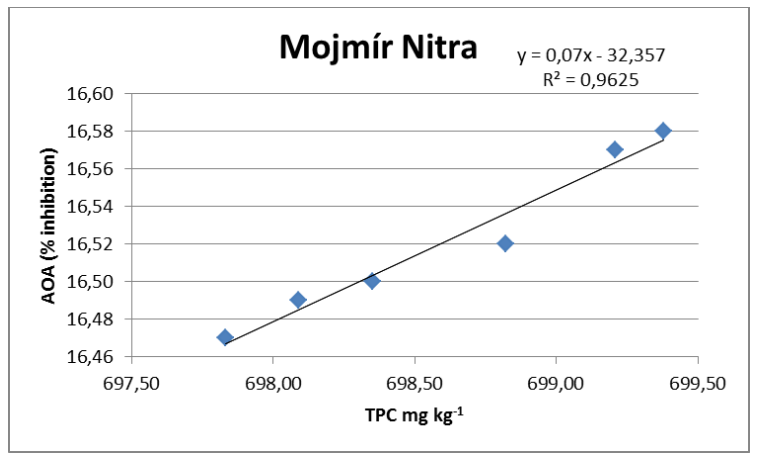

Figure 15: Relationship between TPC and AOA in 'Mojmír'

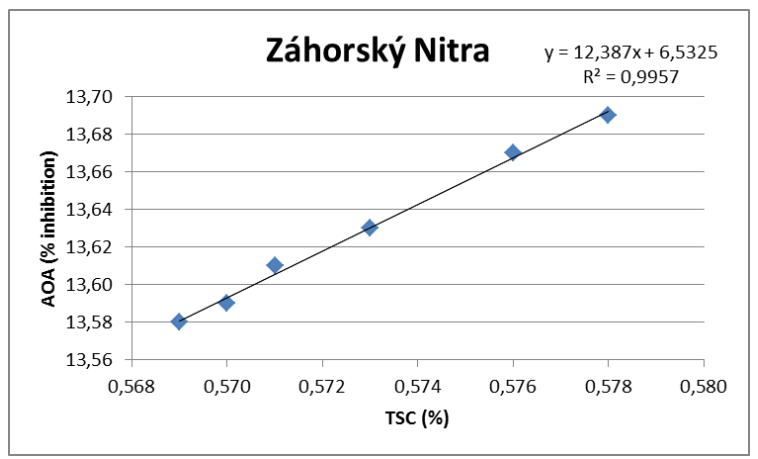

Figure 16: Relationship between TSC and AOA in 'Záhorský' 


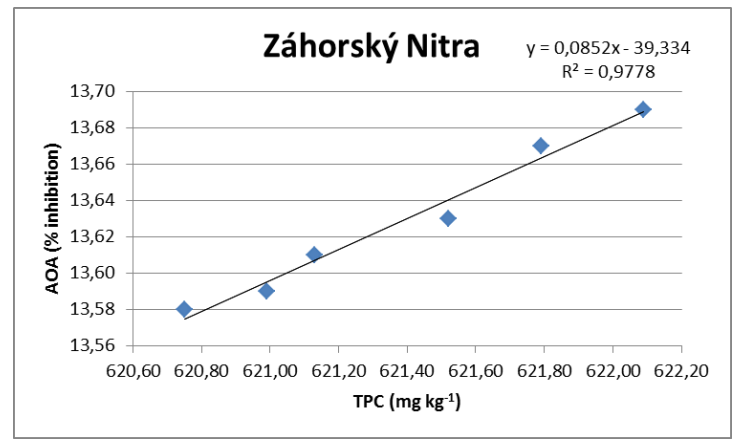

Figure 17: Relationship between TPC and AOA in 'Záhorský'

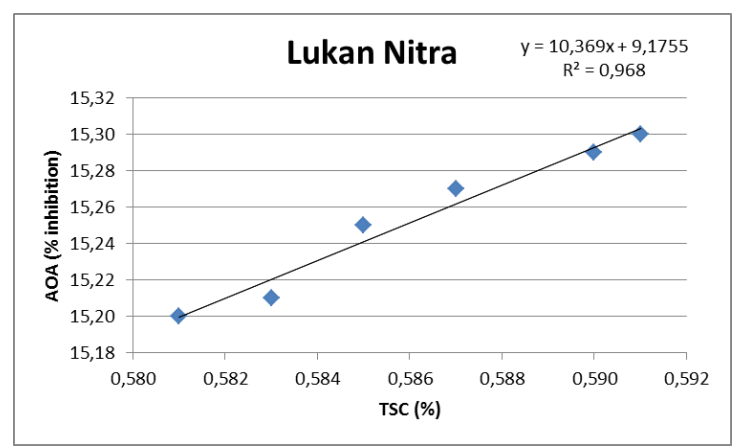

Figure 18: Relationship between TSC and AOA in 'Lukan'

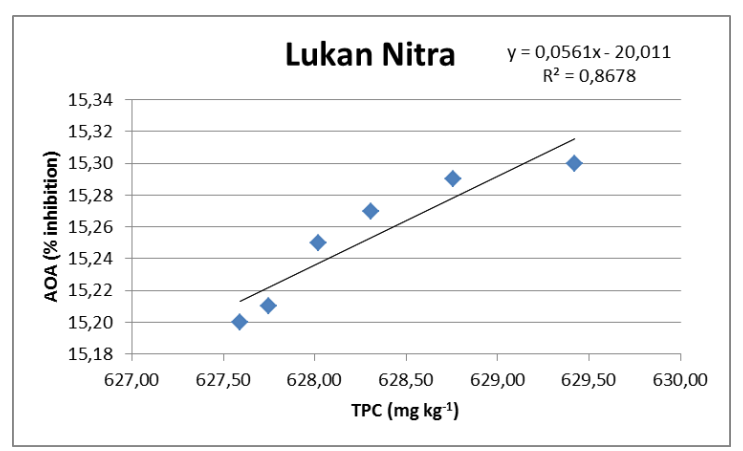

Figure 19: Relationship between TPC and AOA in 'Lukan'

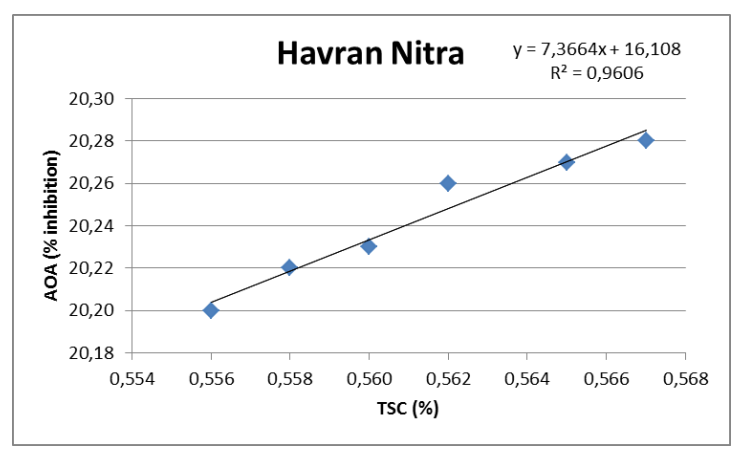

Figure 20: Relationship between TSC and AOA in 'Havran' 


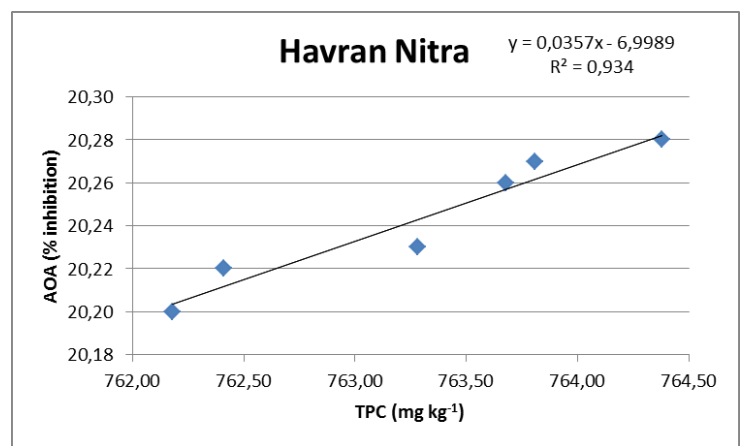

Figure 21: Relationship between TPC and AOA in 'Havran'

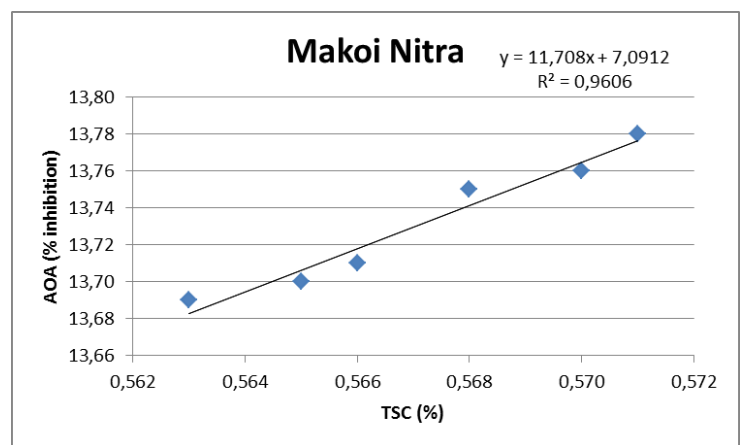

Figure 22: Relationship between TSC and AOA in 'Makoi'

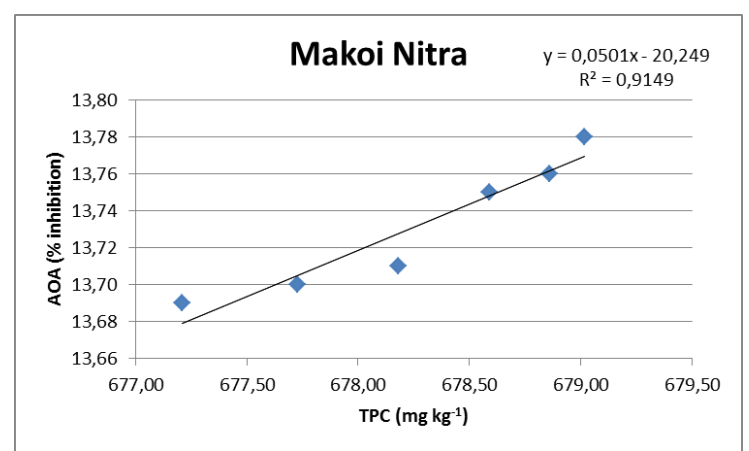

Figure 23: Relationship between TPC and AOA in 'Makoi'

\section{CONCLUSIONS}

The total polyphenols content, the total sulphur content and antioxidant activity in studed varieties of garlic in the both locality were comparable with the literature. We observed statistically significant differences between the analysed varieties of garlic and the monitored indicators. In this work was measured and evaluated the total polyphenols content, the total sulphur content and antioxidant activity of the studied varieties of garlic in the area of Nitra and Bardejov, Slovak Republic. Higher values of the monitored parameters (TPC, TSC, and AOA) were measured in the area of
Nitra. This area is characterized by a higher number of sunny days with a higher average annual temperature, lower annual rainfall and lower altitude. The coefficient of correlation confirmed strong dependency between the total content of polyphenols, total sulphur content and the antioxidant activity. Climatic factors (such as temperature, sunny days, rainfall) and environmental factors, such as soil type, nutrient level and application strategy, influence the nutrient supply to the plant and could thereby affect concentrations and composition of the bioactive compounds in garlic. 


\section{ACKNOWLEDGEMENTS}

This work was supported by scientific grant VEGA

1/0139/17, VEGA 1/0114/18, KEGA 011SPU-4/2017.

\section{REFERENCES}

Ali, L., Alsanius, B., Rosberg, A., Svensson, B., Nielsen, T., Olsson, M. E. (2012). Effects of nutrition strategy on the levels of nutrients and bioactive compounds in blackberries. European Food Research and Technology, 234(1), 33-44. doi:10.1007/s00217-011-1604-8

Amagase, H., Petesch, B. L., Matsuura, H., Kasuga, S., Itakura, Y. (2001). Intake of Garlic and Its Bioactive Components. The Journal of Nutrition, 131, 955-962. doi:10.1093/jn/131.3.955S

Benkeblia, N., \& Lanzotti, V. (2007). Allium Thiosulfinates: chemistry, biological properties and their potential utilization in food preservation. Food, 1(2), 193-201.

Bhuiyan, A., Papajani, V. T., Paci, M., Melino, S. (2015). Glutathione-Garlic Sulfur Conjugates: Slow Hydrogen Sulfide Releasing Agents for Therapeutic Applocations. Molecules, 20, 1731-1750. doi:10.3390/molecules20011731

Borek, C. (2001). Antioxidant Health Effects of Aged Garlic extracts. The Journal of Nutrition, 131(3), 1010-1015. doi:10.1093/jn/131.3.1010S

Brand-Williams, E., Cuverlier, M. E., Berset, C. (1995). Use of free radical method to evaluate antioxidant activity. Lebensmittel Wissenschaft und Techologie, 11, 925-929. doi:10.1016/S0023-6438(95)80008-5

Butt, S. M., \& Sultan, T. M. (2009). Garlic: Nature's Protection Against Physiological Threats. Food Science and Nutrition, 49(10), 538-551. doi:10.1080/10408390802145344

Charles, D. J. (2013). Antioxidant properties of spices, herbs and other sources. New York: Springer science. doi:10.1007/978-1-4614-4310-0

Chekki, R. Z., Snoussi, A., Hamrouni, I., Bouzouita, N. (2014). Chemical composition, antibacterial and antioxidant activities of Tunisian garlic (Allium sativum) essential oil and ethanol extract. Mediterranean Journal of Chemistry, 3(4), 947956. doi:10.13171/mjc.3.4.2014.09.07.11

Chekki, R., Najjaa, H., Zouari, N., Máthé, Á., Bouzouita, N. (2016). Detection of organo-sulphur volatiles in Allium sativum by factorial design. Natural Products Chemistry \& Research, 4, 211. doi:10.4172/2329-6836.1000211
Choi, S., Cha, H. S., Lee, Y. S. (2014). Physicochemical and antioxidant properties of black garlic. Molecules, $19, \quad 16811-16823$. doi:10.3390/molecules191016811

Fertout-Mouri, N., Latreche, A., Mehdadi, Z., Bénali, F. T., Bassou. (2014). The Effect of Altitude and Development stage on the Synthetic Activity of some Polyphenols in Teucrium polium L. in Tessala Mountains (Western Algeria). Advances in Environmental Biology, 8, 193-201.

Fulder, S. (2002). O česneku. Praha: Pragma.

Ghasemi, K., Ghasemi, Y., Ehteshamia, A., Nabavi, S. M., Nabavi, S. F., Ebrahimzadeh, M. H., Pourmord, H. (2011). Influence of Environmental Factors on Antioxidant Activity, Phenol and Flavonoids Contents of walut (Juglans regia L.) green huskd. Journal of Medicinal Plants Research, 5, 11281133.

Hamouz, K., Lachman, J., Hejtmánková, K., Pazderů, K., Čížek, M., Dvořák, P. (2010). Effect of natural and growing conditions on the content of phenolics in potatoes with different flesh color. Plant, Soil and Environment, 56(8), 368-374. doi:10.17221/49/2010-PSE

Hamzah, R. U., Jigam, A. A., Makun, H. A., Egwin, E. C. (2013). Antioxidant properties of selected African vegetables, fruits and mushrooms: A Review. Intech, 203-250. doi:10.5772/52771

Harris, J. C. (2004). Antimicrobial properties of Allium sativum. Revija Applied Microbiology and Biotechnology, 57(3), 282-286. doi: $10.1007 / \mathrm{s} 002530100722$

Huchette, O., Kahane, R., Auger, J., Bellamy, C. (2005). Influence of environmental and genetic factors on the alliin content of garlic bulbs. Acta Horticulturae, $\quad 688, \quad 93-100$. doi:10.17660/ActaHortic.2005.688.9

Iciek, M., Kwiecien, I., Chwatko, G., Jezewicz, M. S., Pachel, D. K., Rokita, H. (2012). The effect of garlic-derived sulphur compounds on cell proliferation, caspase 3 activity, thiol levels ad anaerobic sulphur metabolism in human hepatoblastoma. Cell Biochemistry and Function, 30, 198-204. doi:10.1002/cbf.1835 
Jastrzebski, Z., Leontowicz, M., Namiesnik, J., Zachwieja, Z., Barton, H., Pawelzik, E., ArancibiaAvila, P., Toledo, F., Gorinstein, S. (2007). The bioactivity of processed garlic (Allium sativum L.) as shown in vitro and in vivo studies on rats. Food and Chemical Toxicology, 45(9), 1626-1633. doi:10.1016/j.fct.2007.02.028

Kačániová, M., \& Tančinová, D. (2012). Prediktívna mikrobiológia v potravinárstve. Nitra: SPU.

Khodadadi, S., Nejadsattari, T., Naqinezhad, A., Ebrahimzadeh, M. A. (2015). Diversity in antioxidant properties and mineral contents of Allium paradoxum in the Hyrcanian forests, Northern Iran. Biodiversitas, 16(2), 281-287. doi:10.13057/biodiv/d160224

Knežević, V. S., Blažeković, B., Bival, Š. B., Babac, M. (2012). Plant Polyphenols as Antioxidant Influencing the Human Health. Phytochemicals as Nutraceuticals - Global Approaches to their Role in Nutrition and Health, 9, 156-180.

Kraus, T. E. C., Zasoski, R. J., Dahlgren, R. A. (2004). Fertility and $\mathrm{pH}$ effects on polyphenol and condensed tannin concentrations in foliage and roots. Plant Soil, 262, 95-109. doi:10.1023/B:PLSO.0000037021.41066.79

Lachman, J., Hejtmánková, A., Dudjak, E. (2003). Content polyphenolic antioxidants and phenolcarboxylic acids in selected parts of yacon. Vitamins 2003- Prírodní antioxidanty a volné radikály. Pardubice.

Lanzotti, V. (2006). The analysis of onion and garlic. In Journal of Chromatography A, 1112(1), 3-22. doi:10.1016/j.chroma.2005.12.016

Mahmutović, O., Tahirović, I., Copra, A., Memić, M., Ibragić, S., Karić, L. (2014). Correlation of Total Secondary Sulfur compounds, Total Phenols and Antioxidant capacity in the Ramsons and Garlic. British Journal of Pharmaceutical Research, 4(23), 2662-2669. doi:10.9734/BJPR/2014/13977

Mudau, F. F., Saondy, P., Toit, E. S. (2007). Effects of nitrogen, phosphorus and potassium nutrition on total polyphenol content of Bush Tea (Athrixia phylicoides L.) Leaves in Shaded Nursery Environment. Horticultural Science, 42, 334-338.

Munch, R. (2013). Deodorization of garlic breathe volatiles by food and food components. Graduate Program in Food Science \& Technology, 66. doi:10.1111/1750-3841.12394

Muradić, S., Karačić, D., Mahmutović, O., Mutović, F., Sofić, E., Kroyer, G. (2010). Total sulphur and organosulphur compounds in garlic and ramsons plant organs at the end of vegetative period. Planta Medica, 76, 292. doi:10.1055/s-0030-1264590

Narendhirakannan, R. T., Rajeswari, K. (2010). In vitro antioxidant properties of three varieties of Allium sativum L. extracts. Journal of Chemistry, 7, 573579. doi:10.1155/2010/283627

Oberbeil, K., \& Lentzová, CH. (2005). Ovocie a zelenina ako liek. Bratislava: Fortuna.

Obied, H. K. (2013). Biography of biophenols: past, present and future. Functional Foods In Health and Disease, 3(6), 230-241. doi:10.31989/ffhd.v3i6.51

Pereira, D., Valentao, P., Pereira, J. A., Andrade, P. B. (2009). Phenolics: From Chemistry to Biology. Molecules, $\quad 14, \quad 2202-2211$. doi:10.3390/molecules 14062202

Petrovská, B. B., \& Čekovská, S. (2010). Extracts from the history and medical properties of garlic. Pharmacognosy Review, 4(7), 106-110. doi:10.4103/0973-7847.65321

Piazzon, A., Vrhovšek, U., Masuero, D., Mattivi, F., Mandoj, F., Nardini, M. (2012). Antioxidant activity of Phenolic acids and their Metabolites: Synthesis and Antioxidant properties of the sulfate derivatives of ferulic and coffeic acids and of the acyl glucuronide of ferulic acids. Journal of Pharmacy and Pharmacology, 64(8), 1119-1127. https://doi:10.1021/jf304076

Rai, CH., Bhattacharjee, S., Nandi, N., Bhattacharyya, S. (2015). Influence of blanching on antioxidant and antimicrobial activities of raw garlic (Allium sativum). Indo American Journal of Pharmaceutical sciences, 2(6), 1071-1076.

Ramkissoon, H., Weiler, B., Smith, L. D. G. (2012). Place attachment and pro-environmental behaviour in national parks: the development of a conceptual framework. Journal of Sustainable Tourism, 20(2), 257-276. doi:10.1080/09669582.2011.602194

Ruan, J. Y., Wu, X., Härdter, R. (1999). Effects of potassium and magnesium nutrition on quality components of different types of tea. Journal of the Science of Food and Agriculture, 79(1), 47-52. doi:10.1002/(SICI)10970010(199901)79:1<47::AID-JSFA172>3.0.CO;2-A

Sárosi, S., Bernáth, J., Burchi, G., Antonetti, M. (2011). Effect of different plant origins and climatic conditions on the total phenolic content and total antioxidant capacity of self-heal (Prunella vulgaris L.). Acta horticulturae, 925, 49-55. doi:10.17660/ActaHortic.2011.925.5

Srivastava, M. P., Tiwari, R., Sharma, N. (2013). Assessment of phenol and flavonoid content in the 
plant materials. Journal on New Biological Reports, 2(2), 163-166.

Suleria, H. A. R., Butt, M. S., Khalid, N., Sultan, S., Raza, A., Aleem, M., Abbas, M. (2015). Garlic (Allium sativum): diet based therapy of $21 \mathrm{st}$ century. Asian Pacific Journal of Tropical Disease, 5(4), 271-278. doi:10.1016/S2222-1808(14)607829

Sultan, M. T., Butt, M. S., Qayyum, M. M., Suleria, H. A. (2014). Imunnity: plants as effective mediators. Critical Reviews in Food Science and Nutrition, 54(10), 1298-1308. doi:10.1080/10408398.2011.633249

Süli, J., Homzová, K., Sobeková, A., Hrušková, T. (2014). Fyziologické účinky polyfenolov a ich metabolitov v strave. Diabetologie Metabolismus Endokrinologie Vyživa, 17(3), 162-170.

Šapčanin, A., Jancan, G., Pazalja, M., Kresić, D., Pehlić, E., Uzunović, A. (2013). Determination of Total Sulphur Content in Biological Samples by
Using High Performance Ion Chromatography and Elemental Analysis. Bulletin of the Chemists and Technologists of Bosnia and Herzegovina, 41, 1114.

Viljevac Vuletić, M., Dugalić, K., Mihaljević, I., Tomaš, V., Vuković, D., Zdunić, Z., Puškar, B., Jurković, Z. (2017) Season, location and cultivar influence on bioactive compounds of sour cherry fruits. Plant, Soil Environment, 63, 389-395. doi:10.17221/472/2017-PSE

Wangcharoen, W., \& Morasuk, W. (2009) Effect of heat treatment on the antioxidant capacity of garlic. Maejo International Journal of Science and Technology, 3(01), 60-70. doi:10.2306/scienceasia1513-1874.2013.39.246

Xiao, J. B., Kai, G. Y., Yamamoto, K., Chen, X. Q. (2013). Advance in Dietary Polyphenols as $\alpha$ glucosidases inhibitors: A Review on structureactivity relationship aspect. Critical Reviews in Food Science and Nutrition, 53, 818-836. doi:10.1080/10408398.2011.561379 